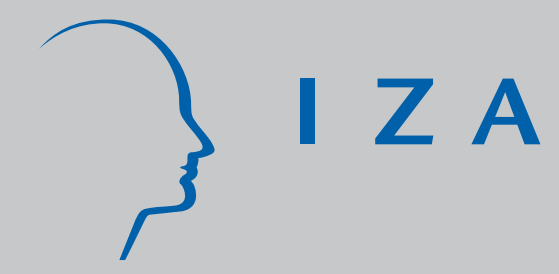

IZA DP No. 160

A Comparison of the Human Capital and Signaling Models: The Case of the Self-Employed and the Increase in the Schooling Premium in the 1980's

Magnus Lofstrom

June 2000 


\title{
A Comparison of the Human Capital and Signaling Models: The Case of the Self-Employed and the Increase in the Schooling Premium in the 1980's
}

\author{
Magnus Lofstrom \\ IZA, Bonn \\ Discussion Paper No. 160 \\ June 2000 \\ IZA \\ P.O. Box 7240 \\ D-53072 Bonn \\ Germany \\ Tel.: +49-228-3894-0 \\ Fax: +49-228-3894-210 \\ Email: iza@iza.org
}

This Discussion Paper is issued within the framework of IZA's research area The Future of Work. Any opinions expressed here are those of the author(s) and not those of the institute. Research disseminated by IZA may include views on policy, but the institute itself takes no institutional policy positions.

The Institute for the Study of Labor (IZA) in Bonn is a local and virtual international research center and a place of communication between science, politics and business. IZA is an independent, nonprofit limited liability company (Gesellschaft mit beschränkter Haftung) supported by the Deutsche Post AG. The center is associated with the University of Bonn and offers a stimulating research environment through its research networks, research support, and visitors and doctoral programs. IZA engages in (i) original and internationally competitive research in all fields of labor economics, (ii) development of policy concepts, and (iii) dissemination of research results and concepts to the interested public. The current research program deals with (1) mobility and flexibility of labor markets, (2) internationalization of labor markets and European integration, (3) the welfare state and labor markets, (4) labor markets in transition, (5) the future of work, (6) project evaluation and (7) general labor economics.

IZA Discussion Papers often represent preliminary work and are circulated to encourage discussion. Citation of such a paper should account for its provisional character. 
IZA Discussion Paper No. 160

June 2000

\section{ABSTRACT \\ A Comparison of the Human Capital and Signaling Models: The Case of the Self-Employed and the Increase in the Schooling Premium in the 1980's*}

This paper utilizes the self-employed to analyze the observed increase in the educational earnings premium in the 1980's. The paper compares the predictions of the signaling and human capital models in response to an exogenous demand shock such as a skill-biased technological change. Since the self-employed have no incentive to invest in a costly signal to show to employers their productivity, a change in the schooling equilibrium should not affect their earnings. Four testable hypotheses are derived. The findings suggest that the signaling model may indeed predict the observed changes in the schooling premium that are not consistent with the predictions of the human capital model.

JEL Classification: J23, J24, J31, D31

Keywords: Earnings inequality, signaling, human capital model, schooling premium, returns to education

Magnus Lofstrom

IZA

P.O. Box 7240

D-53072 Bonn

Germany

Tel.: +492283894303

Fax: +492283894210

E-mail: lofstrom@iza.org

\footnotetext{
* I am grateful to James Rauch for suggesting using the self-employed to analyze changes in earnings inequality and to Julian Betts for several helpful suggestions.
} 


\section{Introduction}

The observed increase in the U.S. educational earnings premium in the 1980's is a well-known economic phenomenon and is also one important factor in explaining the increase in earnings inequality during the same period. The causes of the increase in earnings dispersion are however not generally agreed upon. Explanations include the increase in international trade, immigration, de-unionization and the drop in the real value of the minimum wage. Although these factors have been shown to be important in explaining some of the increase in the dispersion of earnings, none seems to satisfactory explain changes both within and between sectors or groups defined by education or experience.

Given that the number of college educated individuals increased in the 1980's, an increase in the relative demand for more educated individuals appears to be the dominating force behind the increase in the educational earnings premium. The explanation most commonly, and maybe most convincingly, that has been put forward is a skill-biased technological change (see for example Bound and Johnson, 1992).

In this paper I test whether the increase in earnings inequality and the educational earnings premium in the U.S. in the 1980's is consistent with the predictions of a signaling model, originally developed by Spence (1973) and Stiglitz (1975). Krugman (1998) suggested the possibility that a signaling model could help explain the observed increases in earnings inequality. The question posed is: can an increase in the proportion of "high-productivity" workers who choose to obtain higher levels of education to distinguish themselves from "low-productivity" workers explain the trend? If so, the 
average quality of low education level workers will be lowered and would consequently increase the earnings gap between them and higher schooled workers. To test this hypothesis I compare changes in the educational earnings premium for wage/salary workers and the self-employed. Self-employed individuals do not have an incentive to obtain the signal that education carries with it and would likely earn their true productivity. Wage/salary workers on the other hand would earn a wage based on the average productivity of their group. The result would be a lower rate of growth of the earnings gap between the high and low educated in the self-employment sector than in the wage/salary sector.

\section{The Signaling Model}

This paper utilizes a version of the well-known signaling model first developed by Spence (1973) and Stiglitz (1975) and later modified by Krugman (1998). In this model workers choose education not to increase their productivity, as in the human capital model, but to signal to employers their productivity. The paper tests the hypothesis that the increase in earnings inequality in the 1980's is related to changes in a signaling equilibrium in which "high-productivity" workers choose higher educational levels to allow them to be distinguished from "low-productivity" workers, as was suggested by Krugman (1998). If this is the case, earnings inequality should not have increased at the same rate for the self-employed in the 1980's.

The model used in this paper to derive testable predictions is Krugman's (1998) version of a signaling model. In this framework there are two types of workers, "good" 
and "bad", and two kinds of jobs, managerial and non-managerial. The managerial jobs require a college degree, which can only be obtained by the "good" workers.

Furthermore, "good" workers are more productive in non-managerial jobs and subsequently earn higher wages in these jobs than "bad" workers do. However, to obtain a higher wage, "good" workers need to obtain a college degree. Krugman also assumes that there are two sectors, one manager intensive and one non-manager intensive. The two inputs in production of the two goods are labor in the form of managers and nonmanagers. The economy is assumed to be open facing a less than perfectly elastic rest-ofworld offer curve. The payoff to education is measured as the ratio of college to nocollege wages. "Good" workers are assumed to invest in a college education if the ratio is sufficiently large. The assumptions lead to two types of labor market regimes, a "human capital" regime and a "quality signaling" regime.

In the human capital regime college educated workers are only employed in managerial jobs. Since a college degree is necessary for these jobs, education in this regime is socially productive. The college premium in this regime is simply the ratio of the managerial to non-managerial wages. Krugman notes that the relationship between the relative wage and the number of college graduates can be either positive or negative, but "if the effect of factor supplies on relative prices is strong and the 'screening' effect is weak" the relationship is negative, i.e. downward sloping, in the human capital regime.

The quality signaling regime takes place when some "good" workers are working in non-managerial positions. In this regime, education simply works as a signal to employers of the productivity of the non-managerial workers. Both college educated and non-college educated "good" workers are employed as non-managers. The college 
educated workers will receive a higher wage proportional to their higher productivity. Note that since "good" workers are more productive in the non-managerial jobs than "bad" workers, the non-managerial wage will be higher than the marginal revenue product of the "bad" workers, as long as not all "good" workers invest in the signal. This also implies that if the number of good workers who receive a college degree, and therefore are able to separate themselves from the "bad" workers, increases, the nocollege wage will decrease. In other words, the relationship between the college premium and the number of good worker who obtain the signal is positive or upward sloping.

An obvious question is which labor market regime will prevail? The answer will depend on which regime offers the highest relative wage for a given number of "good" workers who obtain a college degree. The relationship between the relative wage and the number of college graduates is downward sloping in the human capital regime and upward sloping in the quality signaling regime. Assuming an intercept of the two relationships exists, the regime offering the highest relative wage will take place. For example, if college graduates can receive higher wages as non-managers than managers, for a given number of college graduates, some of them will shift over to non-managerial positions. This implies that we are in a quality signaling regime.

Based on the model described above, there are multiple locally stable equilibria. One possible equilibrium is that only some "good" workers get a college education and the economy is in the human capital regime. It is also possible that all "good" workers invest in education and the quality signaling regime is observed. Krugman also shows that there are unstable equilibria as long as it is assumed that the number of college 
graduates increase with an increase in the relative wage. The equilibrium that the economy will be in is determined by history.

Krugman shows that it possible for an economy to move from a relatively egalitarian human capital regime equilibrium to a quality signaling equilibrium. This may happen if there is an increase in the demand for managers, due possibly to an increase in the demand for manager intensive goods abroad or a manager biased technical change. The important point is that it is only necessary for this exogenous shock to push the human capital regime to some critical point. After reaching this point, the economy is pushed out of the human capital regime equilibrium into a temporary unstable quality signaling equilibrium. At this point, as more "good" workers obtain a college degree, the college premium increases. This in its turn increases the incentive for other "good" workers to invest in education. The economy will eventually reach a quality signaling regime equilibrium where all "good" workers are college graduates. Note that the exogenous shock does not need to be particularly large; it only needs to push the economy out of the egalitarian equilibrium to a critical point. From this point on, the continuous increase in educational attainment of "good" workers simply "feeds on itself".

What has been observed in the U.S. in the 1980's is consistent with the model described above. If there has been an exogenous shock such as described by Krugman and the signaling model accurately describes the schooling choice of workers, we would expect to observe both an increase in the mean educational attainment levels and an increase in the college earnings premium. The model also predicts a decline in the earnings of the least skilled. The drop in the wages of relatively low educated workers has been found to be one important factor in explaining the observed increase the 
educational earnings premium and consequently the increase in earnings inequality in the U.S.

A human capital model can predict similar changes in wages for employees following an exogenous shock, although it is less clear in such a model whether the wages of less educated workers would decline in relative or absolute terms. Nevertheless, it becomes possible to test the signaling model informally against the human capital model by considering how the two theories differ in their predictions for employees and self-employed workers. If the signaling model is correct, an exogenous shock should have quite different effects on the earnings of self-employed workers and employed workers. In contrast, if the human capital model of education is correct, then there should be little difference between the impact of technical change on the "returns" to education in the wage/salary and self-employed sectors, since the marginal revenue product of workers should change in similar ways in the two sectors. In this way, I can indirectly test the signaling theory against the human capital theory.

To test whether the above signaling model is consistent with U.S. data for the 1980 's I will compare changes in the educational earnings premium for wage/salary workers and the self-employed. Obtaining a signal is unnecessary for the self-employed since it is costly and does not increase earnings. An apparent question is: if the signaling model correctly describes the schooling choice and markets are perfect, why do selfemployed individuals obtain any education? One obvious reason is that some education is required by law. It is also possible that education has consumption value. Another conceivable rationalization is that some self-employed individuals did not anticipate becoming self-employed and made their educational choice based on the expected returns 
in the wage/salary sector. Assuming that one will work in the wage/salary sector when making the schooling decision seems reasonable since close to 90 percent of the labor force work in this sector. Also, some self-employed individuals who provide some professional services, for example accountants and stockbrokers, may need to obtain credentials to signal to consumers their ability to provide the service. Furthermore, for some occupations formal post-secondary education is a prerequisite. Most notable are lawyers, architects, engineers and physicians. For these reasons, the trends in educational attainment of the self-employed are predicted to somewhat resemble those of wage/salary workers, but are likely to be less pronounced.

The model utilized in this paper and the use of the self-employed as a "control" group leads to four testable predictions. The underlying assumption is that the human capital model would predict equal changes in returns to education for the two groups in response to an exogenous shock, such as described above, when relevant earnings factors are controlled for. The hypotheses are presented below.

1) The signaling model illustrated above predicts that the schooling premium for wage/salary workers will increase as a new equilibrium is reached. The selfemployed are expected to face no increase in the earnings premium, according to the signaling model. However, the earnings of some self-employed are likely to be influenced by the wage/salary sector. Earnings of groups for whom postsecondary schooling is required are likely to be at least partially determined by the larger wage/salary sector. The testable prediction is that the returns to education increased by less for the self-employed than for employees. 
2) The model also predicts that the average "quality" of the lower ability, or education, group will be lower in the new equilibrium. The reason for this is that the most able ones who have not yet obtained the signal are also the ones most likely to increase their educational attainment level due to their relatively lower cost of obtaining the signal. Since the relatively more able entrepreneurs do not have the incentive to increase their educational attainment, the drop in "quality" of the relatively low-ability self-employed is predicted to be less. This implies that earnings of the least educated self-employed should have increased during the 1980 's compared to the earnings of the least educated wage/salary workers.

3) The earnings of the most highly educated self-employed individuals are predicted to be most affected by the changes in earnings of wage/salary workers (this is the group for which a degree is most likely to be either required, or for which it is necessary to obtain a signal to convince clients of one's ability). Hence, the difference in the change in schooling premium between the two sectors is expected to be less for the post-graduate attainment group than for the college group.

4) Excluding from the sample the occupations for which at least a college degree is required in order to work will increase the difference in changes in the schooling premium for the most educated individuals.

These four testable predictions of the signaling model will be tested using the data described next. 


\section{Data}

The data for this study is drawn from the 1980 5\% A Sample and the $19905 \%$ Sample of the U.S. Census of Population. Included are males between the ages of 18 and 64 who are not residing in group quarters, who are not in military service or enrolled in school, and who reported working at least 40 weeks in the year prior to the census. Given the large data set this leaves us with, I extracted a 20 percent randomly selected subsample of native born Americans from the 5\% Sample, but kept all immigrants ${ }^{1}$. Weights are used and adjusted accordingly (i.e. weights for natives are multiplied by 5). Earnings reported in the tables are weekly wages. These are calculated by dividing annual earnings by the number of weeks worked in the year prior to the census. All tables report two measures of earnings, combined earnings (wage/salary earnings plus self-employment earnings for both groups) and separate earnings (wage/salary earnings only for wage/salary earners and self-employment earnings only for the self-employed). The latter earnings measure is more appropriate for testing the hypotheses above. The reason for this is that the combined earnings measure includes earnings from the other sector. For example, the combined earnings of the self-employed include, if applicable, earnings from wage/salary work. This measure is consequently "clouded" by the changes and trends in wage/salary earnings. However, from a policy perspective, the measure for total earnings, i.e. combined earnings, is the more relevant measure since an individual's well being is determined by total income. Total income is clearly more closely related to total

\footnotetext{
${ }^{1}$ Immigrants have approximately one percent higher self-employment probabilities than natives. Selfemployed immigrants have been found to do better in the labor market than wage/salary immigrants (Lofstrom, 1999). An immigrant fixed effect is included in regressions to account for differences between
} 
earnings than earnings from a particular sector. Overall, there are only a few relatively minor differences in the changes in earnings between the two measures. Since there are only small differences in the results between the two measures, and the more relevant one for testing the signaling hypothesis is separate earnings, the results discussed in the paper will focus on separate earnings. The sample includes individuals who reported separate earnings of at least $\$ 100$ per week in 1989 prices.

\section{Trends and Differences in the Educational Earnings Premium}

The overall trend in real weekly earnings appears to be quite similar for wage/salary employees and the self-employed in the 1980's. Table 1 shows that real weekly separate earnings dropped by approximately 3.5 percent for wage/salary employees and by 4.1 percent for the self-employed. Using the combined earnings measure, it appears that the decline is about half of what the separate earnings measure indicates for the self-employed, 1.9 percent, while it is almost unaffected for wage/salary workers, a decrease of 3.2 percent.

To analyze the changes in the educational earnings premium, five educational attainment groups are defined. The first group consists of individuals with less than 12 years of schooling. This group will interchangeably be referred to as high school dropouts. The second groups is persons with 12 years of education, roughly high school graduates. A group for 13 to 15 years of schooling is created, which will be designated as some college. The last two groups are 16 years of education, which corresponds

immigrants and natives. An interaction dummy variable between immigrant and self-employment status is also included to control for differences between wage/salary and self-employed immigrants. 
approximately to college graduates, and more than 16 years, or roughly post-graduate education ${ }^{2}$.

The changes in earnings by schooling levels in the 1980's display quite different pictures for the two groups, as can be seen in Table 1.Wage/salary workers with less than 12 years of education displayed a drop in earnings of approximately 18.5 percent. The decline for the self-employed with the same educational attainment level was roughly 11 percent. For the wage/salary sector, real wage/salary earnings dropped by 12.3 percent for high school graduates and by 5.2 percent for individuals who have between 13 and 15 years of schooling while it increased by 3.1 percent for college graduates. The greatest increase for employees over the decade was for the most educated group whose earning increased by slightly more than 14 percent.

The earnings of the self-employed dropped by roughly the same percentage for the three non-college degree groups, that is, by about 10-11 percent. For self-employed college graduates earnings decreased as well, but by less, only 3.5 percent. The only group of self-employed that showed an increase in earnings was the post graduate group. The earnings increased by 13.1 , only by one percent less than the increase for this educational attainment group of wage/salary workers.

Changes in the relative earnings between schooling groups in the 1980's appear to be less dramatic for the self-employed than for wage/salary workers. The gap between the highest and lowest educated employees grew by 32.6 percent. For the self-employed this

\footnotetext{
${ }^{2}$ The 1990 Census codes educational attainment differently from the 1980 Censuses. In the 1990 data, I recoded years of schooling in the following way. No school completed, nursery school and kindergarten are recoded as 0 years of schooling; first through fourth grade are recoded as 2.5 years; fifth through eighth grade as 6.5 years; ninth grade as 9 years; tenth grade as 10 years; eleventh grade or twelfth grade without a high school diploma as 11 years; high school graduate as 12 years; some college, no degree as 13 years; associate degree as 14 years; bachelor's degree as 16 years; master's degree as 17 years and professional or
} 
gap increased by 24.1 percent. Wage/salary college graduates increased their earnings advantage over high school dropouts by 21.6 percent while the earnings advantage for self-employed college graduates increased by only 7.5 percent over the decade. This suggests that earnings inequality did not increase as much for the self-employed as it did for employees. The trends are quite similar using combined earnings.

It is possible that the differences in changes in real earnings between wage/salary and self-employed individuals are due to differences in the changes in the educational distribution. In order for the wage of the highly educated to grow relative to the less educated during a period in which the relative supply of highly educated workers grew, as was the case in the 1980 's, the increase in relative demand of educated workers must have been dominating the supply change. If there has been a greater increase in the supply of relatively educated workers among the self-employed during the decade, this might explain the smaller differences in the changes in earnings between educational attainment groups. However, Table 2 shows that the trends in higher schooling levels during the 1980 's are quite similar for the self-employed and wage/salary workers. If anything, the self-employment sector may not have displayed as great of an increase in the supply of relatively skilled individuals. This suggests that we would expect a greater increase in the earnings of the relatively highly educated entrepreneurs than the relatively highly educated workers. Differences in changes in the relative supply of highly educated workers do not appear to offer a good explanation of the difference in earnings trends over educational attainment groups between the self-employed and employees.

doctorate degree as 20 years. It should be noted that the effect of the change in coding on comparisons of educational attainment between census years is unknown. 
The educational earnings premium and changes in it over the decade also differ between the two groups. Table 3 shows that there has been a dramatic increase in returns to education among wage/salary workers. Table 3 also shows that the increase in returns to education has been substantially lower for the self-employed. For example, the average college educated wage/salary worker increased his earnings advantage over the average high school dropout by 21.6 percent. The increase for the self-employed group is only about one third, or 7.5 percent. Furthermore, it appears that self-employed individuals with high school degree or more, but no college degree, have barely, if at all, increased their earnings advantage over high school dropouts.

The observed differences in the changes of the educational earnings premium are, on the surface, consistent with the model prediction of smaller increases in the schooling premium for the self-employed. However, there are many factors that need to be controlled for to reliably test the predictions of the model.

The greater increase in the earnings premium of wage/salary workers relative to the self-employed may be caused by changes in wage setting institutions. For example, the drop in unionization rates has been shown to cause a decrease in the economic position of the relatively less educated workers (see for example Blackburn, Bloom and Freeman, 1991 and Freeman, 1993). Since the self-employed are clearly not unionized, any changes in earnings inequality and the educational earnings premium caused by the decline in union membership rates will only affect workers in the wage/salary sector. The impact is most likely to affect "between-industry" earnings differentials since unionization rates vary substantially across industries. A comparison of changes in returns to education by industry will partially control for the decline in unionization rates. 
It should also be noted that union density has only been found to explain a relatively small part of the earnings premium. Freeman (1993) estimates that between 15 and 40 percent of the increase in the college premium can be attributed to the downward trend in union participation rates.

Educational earnings premiums are presented by 10 broadly defined industries in Table 4. There is considerable variation in returns to education over industries. There are also differences in these returns between the wage/salary sector and the self-employment sector in a particular industry. More importantly to this paper, the increase in the earnings premium from education in the 1980 's is less for the self-employed in virtually all industries, and the earnings premium has even declined in some industries.

\section{Econometric Results}

There are numerous factors that may have affected the educational earnings premium differently for wage/salary workers and the self-employed. Potential factors include changes in, and composition of, individuals' geographic location, marital status, disability, immigrant status, returns to labor market experience and industrial composition. To account for these factors regressions of log weekly earnings functions are estimated.

The educational earnings premium will be measured in the same way as above, i.e. the difference in earnings between individuals with less than 12 years of education and the four groups defined by 12 years (ED12 in the earnings equation below), 13 to 15 years (ED1315), 16 years (ED16) and more than 16 years of schooling (ED1720). The 
model includes the latter four variables, using the lowest educational attainment group, high school dropouts, as the reference group. The model also includes dummy variables for self-employment, a 1990 period effect and interactions of these with each other and the education dummies. The full model is presented in the equation below.

$$
\begin{aligned}
\ln w_{i} & =\alpha+\beta \mathbf{X}_{i}+\varphi 1990 \text { Census }_{i}+\phi S E L F E M P L_{i}+v S E * 1990_{i} \\
& +\tau_{1} E D 12_{i}+\tau_{2} E D 1315_{i}+\tau_{3} E D 16_{i}+\tau_{4} E D 1720_{i} \\
& +\delta_{1} E D 12 * 1990_{i}+\delta_{2} E D 1315 * 1990_{i}+\delta_{3} E D 16 * 1990_{i}+\delta_{4} E D 1720 * 1990_{i} \\
& +\lambda_{1} E D 12 * S E_{i}+\lambda_{2} E D 1315 * S E_{i}+\lambda_{3} E D 16 * S E_{i}+\lambda_{4} E D 1720 * S E \\
& +\gamma_{1} E D 12 * S E * 1990_{i}+\gamma_{2} E D 1315 * S E * 1990_{i} \\
& +\gamma_{3} E D 16 * S E * 1990_{i}+\gamma_{4} E D 1720 * S E * 1990_{i}+e_{i}
\end{aligned}
$$

The estimated coefficients are to be interpreted in the following way. The estimated coefficient on the 1990 period effect, $\hat{\varphi}$, is the change in log weekly earnings from 1979 to 1989 for wage/salary high school dropouts. The estimated coefficient on the interaction between self-employment and the period effect, $\hat{v}$, is consequently the difference in the change of earnings for high school dropouts between employees and the self-employed. The estimated education coefficients, $\hat{\tau}_{j}$ 's, are the educational earnings premiums for wage/salary worker in 1979. The differences in the premiums, in 1979, between the self-employed and workers are shown by the $\hat{\lambda}_{j}$ 's. The $1979-89$ change in the wage/salary schooling premium is estimated by the $\hat{\delta}_{j}$ 's while the difference in the change between the two sectors is estimated by the $\hat{\gamma}_{j}$ 's.

Based on the results of the estimated earnings function, the four testable predictions discussed above can be tested by the following hypotheses.

1) The self-employed experienced a smaller increase in the education premium, $\mathrm{H}_{0}: \hat{\gamma}_{j}<0$. 
2) The earnings of the least educated self-employed increased relative to the earnings of the least educated wage/salary workers, $\mathrm{H}_{0}: \hat{v}>0$

The next two hypotheses follow from the idea that in some occupations a postgraduate degree is required, so that it will be more difficult to distinguish any differences between highly educated employees and self-employed individuals in these occupations.

3) The difference in the change in the schooling premium between the two sectors is expected to be less for the post-graduate attainment group than for the college group, $\mathrm{H}_{0}:\left|\hat{\gamma}_{3}\right|>\left|\hat{\gamma}_{4}\right|$

4) Excluding the occupations for which at least a college degree is required will increase the difference in the change over the decade in the educational earnings premium for the most educated group, $\mathrm{H}_{0}: \hat{\gamma}_{4}>\hat{\gamma}_{4}$, where $\hat{\hat{\gamma}}$ indicates the estimated coefficient from the restricted sample.

Although, these hypothesis tests can be performed on each model estimated, I will mostly restrict discussion of the tests to the most fully specified model. The reason for this is that the estimated coefficients will be biased in the simpler models due to omitted variables. Clearly, if the most specific model also suffers from omitted variable bias, the test results are questionable. However, the most sophisticated model is the model most likely to withstand this problem. Furthermore, this model adjusts for the factors most 
commonly controlled for in earnings functions estimated in the labor economics literature.

The results from estimating equation 1 without the vector $\mathbf{X}$ are shown in Table 5 as Model 1. Note that these coefficients can be used to identify the identical values shown in Table 3. However, it is possible that some of the differences in the changes in the educational earnings premium between wage/salary employees and the self-employed can be explained by differences in changes in, and composition of, individuals geographic location, marital status, disability and immigrant status. To control for this possibility, all of the above mentioned variables are added to the vector $\mathbf{X}$, in addition to interactions with both self-employment and a 1990 period effect. Model 2 in Table 5 shows the results when controls for these factors are included.

The estimated changes in the education premium between 1979 and 1989 for wage/salary workers are represented by the $\hat{\delta}_{j}$ 's from the earnings equation. The changes in the schooling premiums for the self-employed are denoted by the sum $\hat{\delta}_{j}+\hat{\gamma}_{j}$. The changes in educational earnings premium based on the estimated models in Table 5 are shown in Table 6 . The p-values from tests of no change in the schooling premiums are also presented in Table 6 . For wage/salary workers, these are calculated from the hypothesis test $\mathrm{H}_{0}: \hat{\boldsymbol{\delta}}_{j}=0$. For the self-employed the null hypothesis is $\hat{\delta}_{j}+\hat{\gamma}_{j}=0$.

The above mentioned controls appear to have only a small effect on the estimated 1979 schooling premium, the $\hat{\tau}_{j}$ 's and $\hat{\lambda}_{j}$ 's, for both the self-employed and wage/salary workers. However, the change in the premium over the decade declines when the vector $\mathbf{X}$ is added to the model. The effect is particularly strong for the change in the difference 
in earnings between wage/salary high school dropouts and high school graduates. The earnings premium for high school graduates drops from 6 to 3.5 percent for wage/salary workers while it remains around 1 percent for the self-employed. In other words, almost half of the increase in the high school premium for employees can be explained by the factors included in the vector $\mathbf{X}$. Furthermore, the increase in the high school and "some college" premium is insignificant for the self-employed while for employees the estimated increases were 3.5 and 9.5 percent respectively, according to model 2 . The college premium increased in the 1980's for both groups but by considerably less for the self-employed, 17.3 and 6.0 percent respectively.

It is also necessary to control for labor market experience in the earnings model. It is particularly important for the model to allow for possible differences in changes in returns to experience since it has been found that returns to experience also changed in the 1980's (see for example Katz and Murphy, 1992). Model 3 in Table 5 adds a quartic in labor market experience, where experience is measured as age - years of schooling - 6 . These variables are also interacted with self-employment and a 1990 period effect.

Adding the experience controls to the earnings function alters the estimated changes in the schooling premiums substantially. The change in the high school premium for wage/salary workers drop from 3.5 to 0.9 percent. The estimated change in the earnings premiums for some college and college graduates decline from 9.4 to 5.4 percent and from 17.3 to 14.7 percent respectively for employees. The results in Model 3 indicate a decrease, although not significant, in the change in the high school premium for the self-employed. The model also implies a decrease of 2.7 percent, which is statistically significant, in the premium for some college. The increase in the college 
premium for the self-employed was substantially lower than for wage/salary workers. Model 3 indicates an increase by 14.7 percent for employees while the self-employed experienced an increase by only 2.8 percent. The difference in the increase in the schooling premium for individuals with postgraduate training is substantially smaller. Wage/salary workers and entrepreneurs in this schooling group increased their earnings advantage over high school dropouts by 21.2 percent and 17.9 percent respectively.

The self-employed appear to have experienced quite different changes in returns to education in the 1980's, compared to employees. The differences in the change of all the schooling premiums between wage/salary workers and the self-employed are consistent with the predictions of the signaling model described above. This is true when changes in geographic location, marital status, disability, immigrant status and labor market experience are controlled for.

However, as discussed earlier, changes in industrial composition and the decline in unionization rates might explain somewhat the different trends in schooling premiums between the two sectors. The impact is most likely to affect between industry earnings differentials since unionization rates vary substantially across industries. A comparison of changes in returns to education by industry will partially control for the decline in unionization rates. Hence, industry dummies and these dummies interacted with both a 1990 period effect and self-employment are added to the vector $\mathbf{X}$ in model 3. Interaction variables between the industries, self-employment and the 1990 period effect allow for different changes in earnings over the decade for the two sectors. The estimated results are presented in table 5 as model 4 . 
As expected, the estimated changes in education premiums decline somewhat when the industry dummies and interactions are added. The high school premium for wage/salary workers is estimated to have increased by about 0.5 percent, a slight drop compared to the results in model 3. For the self-employed, the model again estimates a statistically non-significant decrease in the high school premium. The 1979-89 change in the wage/salary premium for some college is now 4.6 percent. The premium for this educational attainment group among the self-employed decreased by 2.8 percent over the decade, according to model 4 . The college premium increased by 12.8 percent for employees and by 2.3 percent for the entrepreneurs. The college premium appears to have increased by less than one fifth of the wage/salary premium increase for the selfemployed. Postgraduate education increased earnings relative to high school dropouts by 19.2 percent for workers and by 14.3 percent for the self-employed. I will next turn to the testable predictions of the signaling model. The hypotheses tests will be based on the estimated results of Model 4 in Table 5. The conclusions based on these test results also hold for the simpler models.

The first null hypothesis tested, that the self-employed displayed smaller increases, or even possibly decreases, in the educational earnings premium, is accepted for all schooling groups except high school graduates. This test is performed on the estimated $\hat{\gamma}_{i}$ 's. The estimated coefficient on $E D 12 * S E * 1990, \hat{\gamma}_{1}$, is negative but insignificant. However, the results also indicate that high school graduate employees did not experience any increase in their earnings advantage over high school dropouts.

The second prediction of the signaling model to be tested is whether the least educated entrepreneurs increased their earnings relative to the least educated employees. 
The null hypothesis can be tested based on the estimated coefficient on the interaction between self-employment and the 1990 period effects, $\hat{v}$. The null hypothesis of equal change is rejected. The earnings of the self-employed in this schooling group grew by 10.2 percent more than it did for wage/salary high school dropouts.

The third hypothesis tests whether the difference in the change of the educational earnings premium between the two sectors is less for the post-graduate group than for the college group. It is expected that the earnings of the most educated self-employed individuals will be influenced more by the changes in the earnings of wage/salary workers than the earnings of the relatively less educated entrepreneurs. The reason for this prediction is that a greater proportion of the self-employed in this education group either has to have a higher degree to practice their profession or have to obtain a credential to signal their ability to potential customers. Hence, the earnings trend of the highly skilled in the two sectors are expected to be more similar than the changes in earnings of the relatively less skilled. The null hypothesis of equal change in the schooling premium for the college and post-graduate group is rejected at the 1 percent level.

The fourth hypothesis tests if omitting the sub-sample of the occupations for which at least a college degree is required in order to work increases the difference in the change in the schooling premium of the most educated. To test this hypothesis Model 4 was re-estimated without individuals in occupations that are likely to require at least a college degree ${ }^{3}$. The results are presented as Model 5 in Tables 5 and 6. Excluding these occupations changes the estimated increase in the schooling premium very little for

\footnotetext{
${ }^{3}$ This omitted group consists of architects, accountants, engineers, physicians, dentists, veterinarians, optometrists, podiatrists, pharmacists and lawyers. Mean years of schooling for this sub-sample is 16.82.
} 
wage/salary workers. The greatest impact is, expectedly, on the change in the earnings advantage of the most educated workers, which decreases from 19.2 percent to 15.6 percent. Excluding these occupations decreases the estimated coefficients for the difference between the two sectors in the change over the decade. There is however one exception. The absolute value of $\hat{\gamma}_{4}$, the estimated coefficient on the variable interacting the dummy variables for more than 16 years of education, self-employment and the 1990 period effect, is slightly higher when the restricted sample is used. $\hat{\gamma}_{4}$ is the only estimated $\hat{\gamma}_{i}$ that increases in an absolute sense when Model 4 is re-estimated using the restricted sample. This indicates that excluding the occupations for which at least a college degree is required increases somewhat the difference in the change over the decade in the educational earnings premium for the most educated group. There appears to be some support, although quite weak, for acceptance of the fourth hypothesis.

Overall, I find evidence of support for the four testable predictions of the model presented. The changes observed in the U.S. in the 1980's is consistent with what a signaling model predicts from a change from a human capital regime to a quality signaling regime in response to an exogenous shock. That is, if we move from an equilibrium with relatively low schooling levels to one with higher average attainment levels, we would observe both an increase in educational attainment and in the educational earnings premium. 


\section{Summary and Conclusions}

In this paper I pose the question whether a signaling model can explain the observed increase in the educational earnings premium in the 1980 's, as was suggested by Krugman (1998), and consequently the increase in earnings inequality over this period. I derive testable predictions of a signaling model and use data from the 1980 and 1990 U.S. Censuses to perform hypothesis tests of these predictions. Since the self-employed have no incentive to invest in a costly signal to show to employers their productivity, a change in the schooling equilibrium should not affect their earnings. The self-employed can in essence be used as a control group for testing the predictions of the signaling model.

Both wage/salary workers and the self-employed displayed increases in educational attainment in the 1980's. The self-employed are found to have displayed significantly lower increases, and even some decreases, in the educational earnings premium over the last decade. This is true when several controls allowing for differences between the self-employed and wage/salary workers, including labor market experience and changes in industrial composition, are incorporated in the earnings model. The findings are consistent with the predictions of a signaling model.

The findings in this paper suggest that the signaling model may indeed predict the observed changes in the schooling premium that are not consistent with the predictions of the human capital model. A change in equilibrium due to an exogenous shock is shown to predict the observed changes in the educational distribution and returns to education. 


\section{References}

Blackburn, McKinley L., Bloom, David E. and Freeman, Richard B. "Changes in Earnings Differentials in the 1980's: Concordance, Converges, Causes and Consequences," National Bureau of Economic Research Working Paper, No. 3901, November 1991.

Betts, Julian R. "Technological Change, Sectoral Shifts and the Distribution of Earnings: A Human Capital Model ", Economica, 1994, 61, 475-92.

Bound, John, and George Johnson "Changes in the Structure of Wages in the 1980s: An Evaluation of Alternative Explanations," American Economic Review, June 1992, 371-392.

Freeman, Richard B. "How Much has De-Unionisation Contributed to the Rise in Earnings Inequality?," in S. Danziger and P. Gottschalk, Uneven Tides: Rising Inequality in America, 1993, New York: Russell Sage Foundation, 99-164.

Katz, Lawrence F and Murphy, Kevin M. "Changes in Relative Wages, 1963-1987: Supply and Demand Factors," The Quarterly Journal of Economics, February 1992, 35-78.

Krueger, Alan, "How Computers have Changed the Wage Structure: Evidence from Microdata," Quarterly Journal of Economics, 1993, vol. 108, 33-60.

Krugman, Paul "And Now for Something Completely Different: An Alternative Model of Trade, Education and Inequality," Mimeo 1998.

Levy, Frank and Murnane, Richard J. "U.S. Earnings Levels and Earnings Inequality: A Review of Recent Trends and Proposed Explanations, " Journal of Economic Literature, September 1992, 1333-81.

Lofstrom, Magnus. "Labor Market Assimilation and the Self-Employment Decision of Immigrant Entrepreneurs," IZA Discussion Paper No. 54, August, 1999.

Murphy, Kevin and Welch, Finis. "Industrial Change and the Rising Importance of Skill," in S. Danziger and P. Gottschalk, Uneven Tides: Rising Inequality in America, 1993, New York: Russell Sage Foundation, 101-132.

Snower, Dennis J. "Causes of Changing Earnings Inequality," IZA Discussion Paper No. 29, January 1999.

Spence, Michael. "Job Market Signaling," The Quarterly Journal of Economics, August 1973, 355-74.

Stiglitz, Joseph E. "The Theory of 'Screening,' Education, and the Distribution of Income," The American Economic Review, June 1975, 283-300. 
Table 1.

Changes in Real Log Weekly Earnings for

Males Aged 18-64, 1979-1989.

\begin{tabular}{lcccr}
\hline & $\begin{array}{c}\text { Separate Earnings } \\
\text { Wage/Salary }\end{array}$ & \multicolumn{2}{c}{$\begin{array}{c}\text { Combined Earnings } \\
\text { Self-Employed }\end{array}$} & Wage/Salary Self-Employed \\
\hline \hline & & & & \\
All & -0.0353 & -0.0412 & -0.0324 & -0.0192 \\
Educational Attainment & & & & -0.1001 \\
$\quad$ Less Than 12 Years & -0.1847 & -0.1098 & -0.1840 & -0.0895 \\
12 Years & -0.1235 & -0.1002 & -0.1221 & -0.0806 \\
13-15 Years & -0.0525 & -0.0967 & -0.0499 & -0.0062 \\
16 Years & 0.0313 & -0.0350 & 0.0356 & 0.1562 \\
More than 16 Years & 0.1416 & 0.1314 & 0.1493 & \\
\hline
\end{tabular}

Table 2.

Educational Distribution for Males Ages 18-64, 1980 and 1990.

\begin{tabular}{lrrrrrr}
\hline & \multicolumn{2}{c}{1980} & \multicolumn{2}{c}{1990} & \multicolumn{2}{c}{ Change 1980-1990 } \\
& $\begin{array}{l}\text { Wage/ } \\
\text { Salary }\end{array}$ & $\begin{array}{c}\text { Self- } \\
\text { Employed }\end{array}$ & $\begin{array}{c}\text { Wage/ } \\
\text { Salary }\end{array}$ & $\begin{array}{c}\text { Self- } \\
\text { Employed }\end{array}$ & $\begin{array}{c}\text { Wage/ } \\
\text { Salary }\end{array}$ & $\begin{array}{c}\text { Self- } \\
\text { Employed }\end{array}$ \\
\hline \hline & & & & & & \\
Educational Attainment & & & & & & \\
Less Than 12 Years & $22.6 \%$ & $20.9 \%$ & $16.3 \%$ & $15.4 \%$ & $-6.3 \%$ & $-5.5 \%$ \\
12 Years & $39.2 \%$ & $32.4 \%$ & $31.6 \%$ & $27.2 \%$ & $-7.7 \%$ & $-5.2 \%$ \\
$13-15$ Years & $17.1 \%$ & $17.0 \%$ & $27.1 \%$ & $25.6 \%$ & $9.9 \%$ & $8.5 \%$ \\
16 Years & $11.2 \%$ & $11.4 \%$ & $16.3 \%$ & $15.6 \%$ & $5.1 \%$ & $4.2 \%$ \\
More than 16 Years & $9.8 \%$ & $18.3 \%$ & $8.8 \%$ & $16.2 \%$ & $-1.0 \%$ & $-2.0 \%$ \\
\hline
\end{tabular}


Table 3.

Educational Log Weekly Earnings Differentials, Relative to Less Than 12 Years of Schooling, 1979-1989.

\begin{tabular}{llll}
\hline & 1979 & 1989 & $\begin{array}{c}\text { Change } \\
1979-89\end{array}$ \\
\hline \hline $\begin{array}{l}\text { Separate Earnings } \\
\text { Wage/Salary }\end{array}$ & & & \\
12 Years & 0.1321 & 0.1933 & 0.0612 \\
13-15 Years & 0.2404 & 0.3725 & 0.1321 \\
16 Years & 0.4427 & 0.6586 & 0.2159 \\
More than 16 Years & 0.5672 & 0.8934 & 0.3263 \\
Self-Employed & & & \\
12 Years & 0.1062 & 0.1158 & 0.0095 \\
13-15 Years & 0.1735 & 0.1865 & 0.0131 \\
16 Years & 0.3985 & 0.4732 & 0.0747 \\
More than 16 Years & 0.6999 & 0.9411 & 0.2412 \\
& & & \\
Combined Earnings & & & \\
Wage/Salary & & & \\
12 Years & 0.1324 & 0.1943 & 0.0619 \\
13-15 Years & 0.2422 & 0.3764 & 0.1341 \\
16 Years & 0.4455 & 0.6651 & 0.2195 \\
More than 16 Years & 0.5750 & 0.9083 & 0.3332 \\
Self-Employed & & & \\
12 Years & 0.1321 & 0.1428 & 0.0107 \\
13-15 Years & 0.2258 & 0.2454 & 0.0196 \\
16 Years & 0.4779 & 0.5718 & 0.0940 \\
More than 16 Years & 0.7766 & 1.0329 & 0.2563 \\
\hline
\end{tabular}


Table 4.

Educational Earnings Premiums, Relative to Less Than 12 Years of Schooling, 1979-1989, by Industry.

\section{Earnings Measure: Separate Earnings}

\begin{tabular}{|c|c|c|c|c|c|c|}
\hline \multirow{2}{*}{$\begin{array}{l}\text { Schooling Group } \\
\text { Industry }\end{array}$} & \multicolumn{2}{|c|}{1979} & \multicolumn{2}{|c|}{1989} & \multicolumn{2}{|c|}{ Change 1979-89 } \\
\hline & Wage/Salary & Self-Employed & Wage/Salary & Self-Employed & Wage/Salary & Self-Employed \\
\hline \multicolumn{7}{|l|}{12 Years } \\
\hline Construction & 0.1289 & 0.0745 & 0.1659 & 0.1055 & 0.0370 & 0.0309 \\
\hline Manufacturing & 0.1417 & 0.1435 & 0.1828 & 0.1406 & 0.0411 & -0.0029 \\
\hline Transportation & 0.1190 & 0.1250 & 0.1891 & 0.0504 & 0.0702 & -0.0746 \\
\hline Wholesale Trade & 0.1294 & 0.1583 & 0.1722 & 0.1251 & 0.0428 & -0.0332 \\
\hline Retail Trade & 0.1218 & 0.0828 & 0.1845 & 0.1165 & 0.0627 & 0.0337 \\
\hline Financial & 0.2500 & 0.0565 & 0.2469 & 0.0102 & -0.0031 & -0.0464 \\
\hline Business Services & 0.1400 & 0.0703 & 0.1534 & 0.0773 & 0.0133 & 0.0070 \\
\hline Health Services & 0.0885 & 0.1005 & 0.0912 & 0.2852 & 0.0028 & 0.1847 \\
\hline Professional Services & 0.1895 & 0.2883 & 0.1995 & 0.0429 & 0.0101 & -0.2454 \\
\hline Other & 0.0248 & 0.1711 & 0.2497 & 0.2391 & 0.2249 & 0.0680 \\
\hline \multicolumn{7}{|l|}{ 13-15 Years } \\
\hline Construction & 0.2311 & 0.1238 & 0.3388 & 0.1229 & 0.1077 & -0.0009 \\
\hline Manufacturing & 0.2753 & 0.1355 & 0.3823 & 0.1793 & 0.1070 & 0.0438 \\
\hline Transportation & 0.1683 & 0.0962 & 0.3031 & 0.0645 & 0.1348 & -0.0317 \\
\hline Wholesale Trade & 0.2856 & 0.2077 & 0.3885 & 0.3189 & 0.1029 & 0.1113 \\
\hline Retail Trade & 0.2399 & 0.1230 & 0.3458 & 0.1602 & 0.1059 & 0.0372 \\
\hline Financial & 0.3854 & 0.0957 & 0.4974 & 0.0588 & 0.1121 & -0.0368 \\
\hline Business Services & 0.2965 & 0.1464 & 0.3477 & 0.1690 & 0.0512 & 0.0225 \\
\hline Health Services & 0.2223 & 0.0530 & 0.3230 & 0.2501 & 0.1007 & 0.1970 \\
\hline Professional Services & 0.2973 & 0.4843 & 0.3899 & 0.1814 & 0.0926 & -0.3029 \\
\hline Other & 0.1276 & 0.2443 & 0.4414 & 0.3025 & 0.3138 & 0.0582 \\
\hline
\end{tabular}

Continued.. 
Table 4 Continued:

Educational Earnings Premiums, Relative to Less Than 12 Years of Schooling, 1979-1989, by Industry.

Earnings Measure: Separate Earnings

\begin{tabular}{|c|c|c|c|c|c|c|}
\hline \multirow{2}{*}{$\begin{array}{l}\text { Schooling Group } \\
\text { Industry }\end{array}$} & \multicolumn{2}{|c|}{1979} & \multicolumn{2}{|c|}{1989} & \multicolumn{2}{|c|}{ Change 1979-89 } \\
\hline & Wage/Salary & Self-Employed & Wage/Salary & Self-Employed & Wage/Salary & Self-Employed \\
\hline \multicolumn{7}{|l|}{16 Years } \\
\hline Construction & 0.4297 & 0.1935 & 0.6307 & 0.3529 & 0.2010 & 0.1594 \\
\hline Manufacturing & 0.5339 & 0.3753 & 0.7101 & 0.3892 & 0.1763 & 0.0139 \\
\hline Transportation & 0.2779 & 0.0560 & 0.5136 & 0.0975 & 0.2357 & 0.0416 \\
\hline Wholesale Trade & 0.5286 & 0.4034 & 0.7526 & 0.5885 & 0.2240 & 0.1850 \\
\hline Retail Trade & 0.4235 & 0.2459 & 0.6449 & 0.3301 & 0.2213 & 0.0842 \\
\hline Financial & 0.5778 & 0.2085 & 0.7930 & 0.2855 & 0.2152 & 0.0770 \\
\hline Business Services & 0.5685 & 0.3219 & 0.6795 & 0.3837 & 0.1110 & 0.0618 \\
\hline Health Services & 0.4576 & 0.4817 & 0.6431 & 0.7766 & 0.1855 & 0.2949 \\
\hline Professional Services & 0.4068 & 0.8498 & 0.5590 & 0.5771 & 0.1522 & -0.2727 \\
\hline Other & 0.4728 & 0.3608 & 0.7986 & 0.5005 & 0.3258 & 0.1397 \\
\hline \multicolumn{7}{|l|}{ More Than 16 Years } \\
\hline Construction & 0.4998 & 0.1297 & 0.8099 & 0.3287 & 0.3101 & 0.1991 \\
\hline Manufacturing & 0.6764 & 0.2508 & 0.9534 & 0.3973 & 0.2770 & 0.1465 \\
\hline Transportation & 0.3881 & 0.1846 & 0.7005 & 0.3438 & 0.3124 & 0.1592 \\
\hline Wholesale Trade & 0.6278 & 0.2586 & 0.9504 & 0.5790 & 0.3226 & 0.3204 \\
\hline Retail Trade & 0.4644 & 0.1667 & 0.8422 & 0.2422 & 0.3778 & 0.0755 \\
\hline Financial & 0.7574 & 0.2134 & 1.1517 & 0.4095 & 0.3943 & 0.1961 \\
\hline Business Services & 0.7387 & 0.3183 & 0.9147 & 0.3104 & 0.1760 & -0.0079 \\
\hline Health Services & 0.9009 & 0.8712 & 1.1986 & 1.2101 & 0.2977 & 0.3389 \\
\hline Professional Services & 0.5738 & 0.9132 & 0.8112 & 0.9248 & 0.2374 & 0.0116 \\
\hline Other & 0.6806 & 0.7806 & 1.1232 & 0.8074 & 0.4426 & 0.0268 \\
\hline
\end{tabular}


Table 5.

OLS Models of Log of Weekly Real Earnings for Males Aged 18-64.

Note: t-statistics appear in parentheses. All observations with a reported weekly earnings of less than $\$ 100$ in $\$ 1989$ or who reported working less than 40 weeks in the census year are excluded. The number of observations is 1,098,510 for Models 1 through 4 and 1,029,923 for Restricted Sample Model 5.

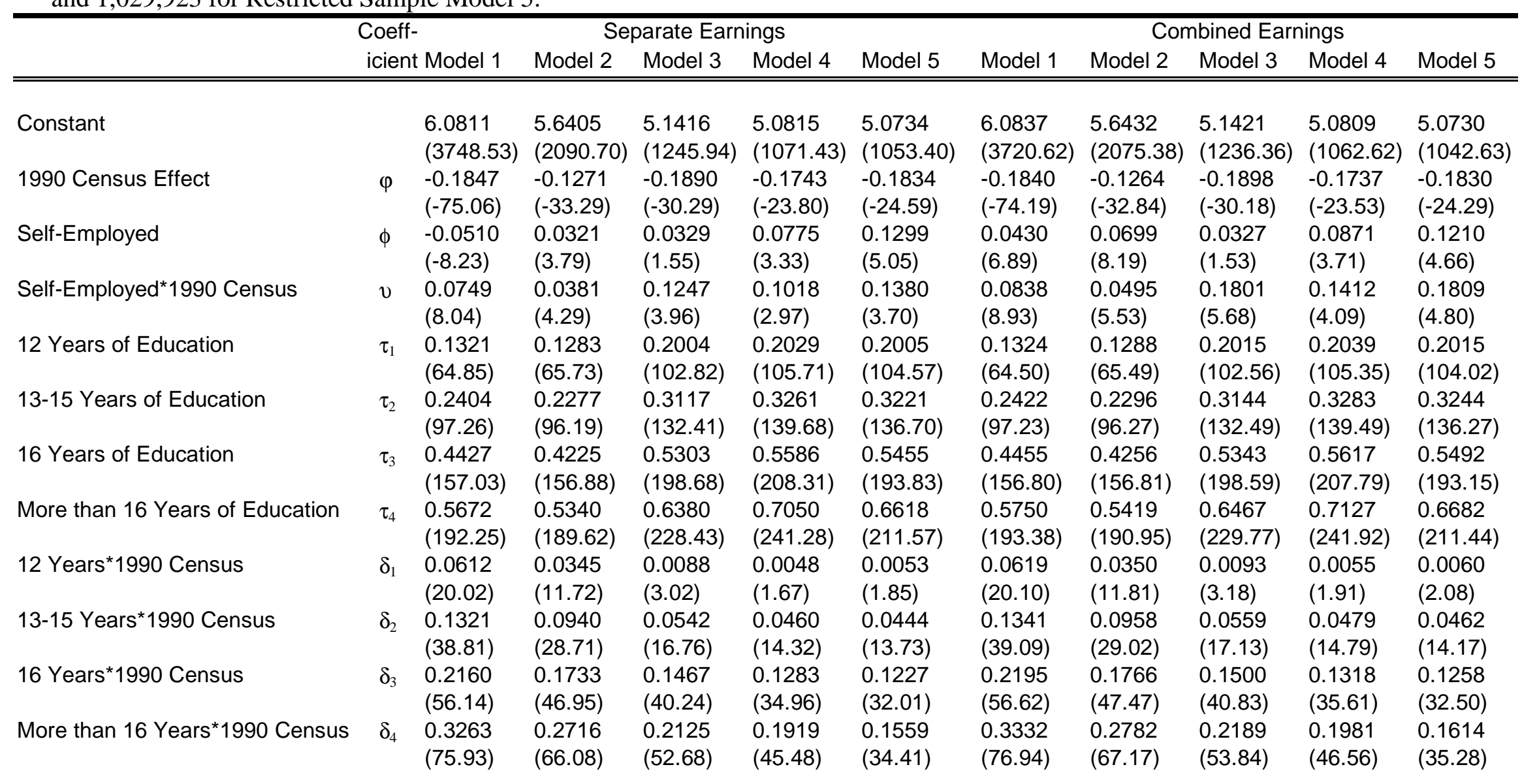


Table 5 Continued:

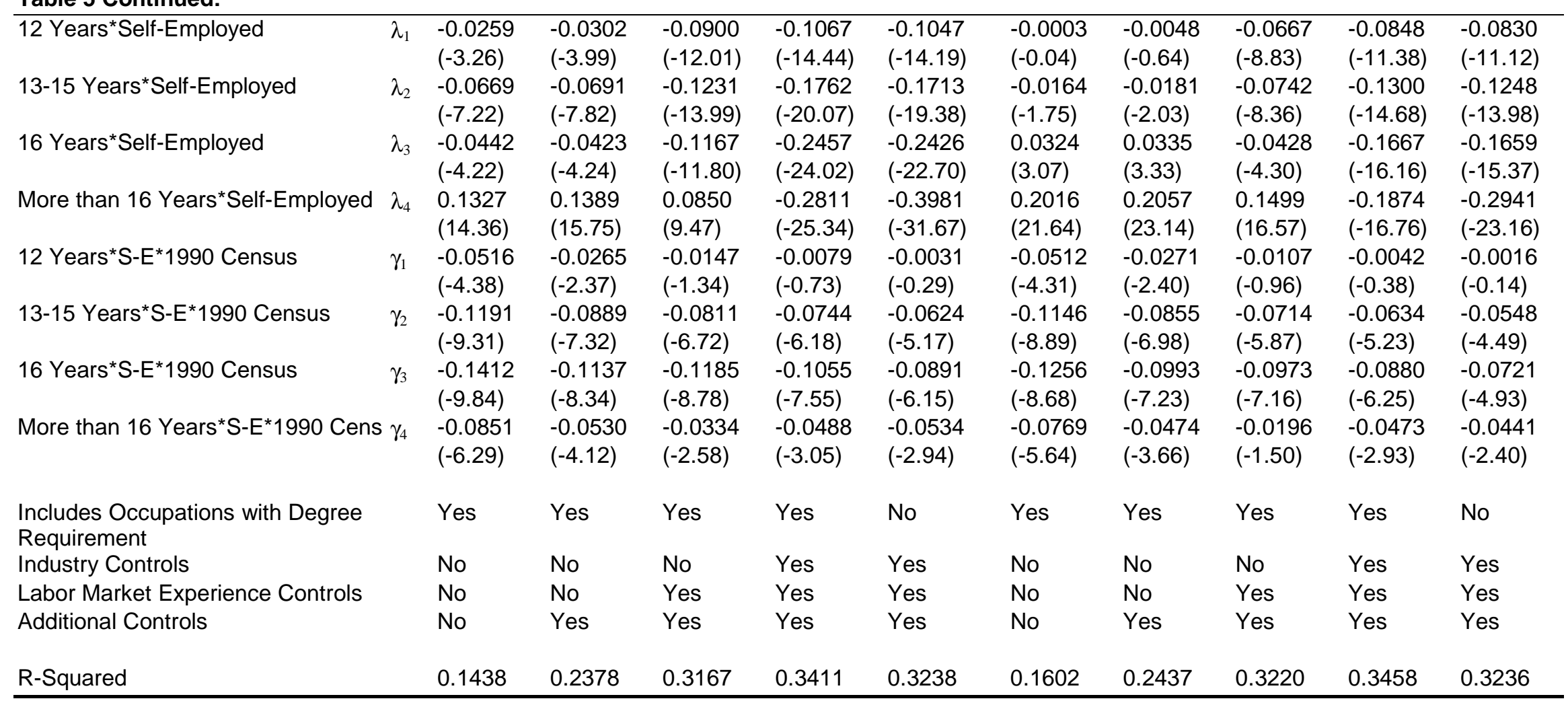


Table 6.

Estimated Changes in the Educational Earnings Premium, 1979-89.

Note: P-values for tests of no change in the earnings premium appear in parentheses. The calculated changes are based on the estimated coefficients presented in Table 5. Hence, model numbers correspond to the model numbers in Table 5.

\begin{tabular}{|c|c|c|c|c|c|}
\hline & \multicolumn{5}{|c|}{ Estimated Change in Education Premium } \\
\hline & lodel 1 & Model 2 & Model 3 & Model 4 & Model 5 \\
\hline \multicolumn{6}{|l|}{ Separate Earnings } \\
\hline \multicolumn{6}{|l|}{ Wage/Salary } \\
\hline \multirow[t]{2}{*}{12 Years } & 0.0612 & 0.0345 & 0.0088 & 0.0048 & 0.0053 \\
\hline & $(0.0001)$ & $(0.0001)$ & $(0.0025)$ & $(0.0944)$ & $(0.0643)$ \\
\hline \multirow[t]{2}{*}{ 13-15 Years } & 0.1321 & 0.0940 & 0.0542 & 0.0460 & 0.0444 \\
\hline & $(0.0001)$ & $(0.0001)$ & $(0.0001)$ & $(0.0001)$ & $(0.0001)$ \\
\hline \multirow[t]{2}{*}{16 Years } & 0.2160 & 0.1733 & 0.1467 & 0.1283 & 0.1227 \\
\hline & $(0.0001)$ & $(0.0001)$ & $(0.0001)$ & $(0.0001)$ & $(0.0001)$ \\
\hline \multirow[t]{2}{*}{ More than 16 Years } & 0.3263 & 0.2716 & 0.2125 & 0.1919 & 0.1559 \\
\hline & $(0.0001)$ & $(0.0001)$ & $(0.0001)$ & $(0.0001)$ & $(0.0001)$ \\
\hline \multicolumn{6}{|l|}{ Self-Employed } \\
\hline \multirow[t]{2}{*}{12 Years } & 0.0096 & 0.0080 & -0.0059 & -0.0031 & 0.0022 \\
\hline & $(0.4019)$ & $(0.4590)$ & $(0.5763)$ & $(0.7663)$ & $(0.8373)$ \\
\hline \multirow[t]{2}{*}{ 13-15 Years } & 0.0130 & 0.0051 & -0.0269 & -0.0284 & -0.0180 \\
\hline & $(0.2894)$ & $(0.6601)$ & $(0.0211)$ & $(0.0144)$ & $(0.1208)$ \\
\hline \multirow[t]{2}{*}{16 Years } & 0.0748 & 0.0596 & 0.0282 & 0.0228 & 0.0336 \\
\hline & $(0.0001)$ & $(0.0001)$ & $(0.0300)$ & $(0.0911)$ & $(0.0162)$ \\
\hline \multirow[t]{2}{*}{ More than 16 Years } & 0.2412 & 0.2186 & 0.1791 & 0.1431 & 0.1025 \\
\hline & $(0.0001)$ & $(0.0001)$ & $(0.0001)$ & $(0.0001)$ & $(0.0001)$ \\
\hline \multicolumn{6}{|l|}{ Combined Earnings } \\
\hline \multicolumn{6}{|l|}{ Wage/Salary } \\
\hline \multirow[t]{2}{*}{12 Years } & 0.0619 & 0.0350 & 0.0093 & 0.0055 & 0.0060 \\
\hline & $(0.0001)$ & $(0.0001)$ & $(0.0015)$ & $(0.0561)$ & $(0.0379)$ \\
\hline \multirow[t]{2}{*}{ 13-15 Years } & 0.1341 & 0.0958 & 0.0559 & 0.0479 & 0.0462 \\
\hline & $(0.0001)$ & $(0.0001)$ & $(0.0001)$ & $(0.0001)$ & $(0.0001)$ \\
\hline \multirow[t]{2}{*}{16 Years } & 0.2195 & 0.1766 & 0.1500 & 0.1318 & 0.1258 \\
\hline & $(0.0001)$ & $(0.0001)$ & $(0.0001)$ & $(0.0001)$ & $(0.0001)$ \\
\hline \multirow[t]{2}{*}{ More than 16 Years } & 0.3332 & 0.2782 & 0.2189 & 0.1981 & 0.1614 \\
\hline & $(0.0001)$ & $(0.0001)$ & $(0.0001)$ & $(0.0001)$ & $(0.0001)$ \\
\hline \multicolumn{6}{|l|}{ Self-Employed } \\
\hline \multirow[t]{2}{*}{12 Years } & 0.0107 & 0.0079 & -0.0014 & 0.0013 & 0.0044 \\
\hline & $(0.3510)$ & $(0.4657)$ & $(0.8960)$ & $(0.9002)$ & $(0.6753)$ \\
\hline \multirow[t]{2}{*}{ 13-15 Years } & 0.0195 & 0.0103 & -0.0155 & -0.0155 & -0.0086 \\
\hline & $(0.1154)$ & $(0.3826)$ & $(0.1864)$ & $(0.1836)$ & $(0.4673)$ \\
\hline \multirow[t]{2}{*}{16 Years } & 0.0939 & 0.0773 & 0.0527 & 0.0438 & 0.0537 \\
\hline & $(0.0001)$ & $(0.0001)$ & $(0.0001)$ & $(0.0013)$ & $(0.0001)$ \\
\hline \multirow[t]{2}{*}{ More than 16 Years } & 0.2563 & 0.2308 & 0.1993 & 0.1508 & 0.1173 \\
\hline & $(0.0001)$ & $(0.0001)$ & $(0.0001)$ & $(0.0001)$ & $(0.0001)$ \\
\hline
\end{tabular}




\section{IZA Discussion Papers}

No. Author(s)

61

62

R. Winkelmann

A. Thalmaier

63

M. Ward

64

M. Ward

65

H. Lehmann

J. Wadsworth

A. Acquisti

66

E. J. Bird

H. Kayser

J. R. Frick

G. G. Wagner

67 R. T. Riphahn

A. Thalmaier

68

B. Dietz

69

M.-S. Yun

70

I. N. Gang

F.L. Rivera-Batiz

71 L. Goerke

72 J. Fersterer

R. Winter-Ebmer

73 G. S. Epstein

S. Nitzan

74 M. Kräkel

75 B. Henry

M. Karanassou

D. J. Snower

76 G. Brunello

M. Giannini

77
Title

Immigration: The New Zealand Experience

Bestimmungsgründe von Fehlzeiten: Welche

Rolle spielt die Arbeitslosigkeit?

Your Everyday, Average Academic

Salary and the Gender Salary Gap in the

Academic Profession

Grime and Punishment: Job Insecurity and Wage

Arrears in the Russian Federation

The Immigrant Welfare Effect: Take-Up or

Eligibility?

Behavioral Effects of Probation Periods:

An Analysis of Worker Absenteeism

Ethnic German Immigration from Eastern Europe and the former Soviet Union to Germany: the Effects of Migrant Networks

Generalized Selection Bias and the Decomposition 6 of Wage Differentials

Immigrants and Unemployment in the European 1

Community

The Wedge

Are Austrian Returns to Education Falling Over

Time?

The Endogenous Determination of Minimum Wage 3

Strategic Mismatches in Competing Teams

Adjustment Dynamics and the Natural Rate: An 1

Account of UK Unemployment

Selective Schools

Knowing What Works: The Case for Rigorous

Program Evaluation
3

5

5

6

Area Date

1

10/99

10/99

10/99

$10 / 99$

10/99

10/99

10/99

$11 / 99$

$11 / 99$

$11 / 99$

$11 / 99$

$11 / 99$

$11 / 99$

$12 / 99$

$12 / 99$

12/99

12/99 
Entrepreneurship from Scratch: Lessons on the

Transition Economies

80 J. C. van Ours

J. Veenman

81 T. J. Hatton

S. Wheatley Price

82 K. A. Konrad

83 R. Euwals

The Netherlands: Old Emigrants - Young

Privacy, time consistent optimal labor income 
M. Rosholm

N. Smith

An Extension of Mortensen and Pissarides (1994)

Ownership or Performance: What Determines

Job Tenure of Two Cohorts of Young German Men 1979 - 1990: An analysis of the (West-)German

Employment Statistic Register Sample concerning multivariate failure times and unobserved heterogeneity

107 J. C. van Ours

Fast Track or Failure: A Study of the Completion 

115 A. Cigno
F. C. Rosati
116 C. Belzil

A. Haas

C. Klose

118 M. A. Shields

M. E. Ward

119 A. Lindbeck

D. J. Snower

120 P. T. Pereira

P. S. Martins

121 J. C. van Ours
117 S. Bender

Why do Indian Children Work, and is it Bad for

3 Them?

Unemployment Insurance and Subsequent Job

Duration: Job Matching vs. Unobserved

Heterogeneity

IAB Employment Subsample 1975-1995.

Opportunities for Analysis Provided by the

Anonymised Subsample

Improving Nurse Retention in the British National Health Service: The Impact of Job Satisfaction on Intentions to Quit

The Division of Labor and the Market for

Organizations

Does Education Reduce Wage Inequality?

Quantile Regressions Evidence from Fifteen

European Countries

Do Active Labor Market Policies Help Unemployed $\quad 4 / 6$ Workers to Find and Keep Regular Jobs?

Returns to Human Capital under the Communist

Wage Grid and During the Transition to a Market

J. Svejnar

K. Terrell

123 J. Hunt

124 R. T. Riphahn

125 F. Büchel

J. R. Frick

126 J. Fersterer

R. Winter-Ebmer

127 M. Karanassou

D. J. Snower

128

O. Ashenfelter

D. Ashmore

O. Deschênes

129 B. R. Chiswick

M. E. Hurst

130 G. Brunello

S. Comi

C. Lucifora

131 B. R. Chiswick
Economy

Why Do People Still Live in East Germany? 1

$3 / 00$

Rational Poverty or Poor Rationality? The Take-up 3

$3 / 00$

of Social Assistance Benefits

The Income Portfolio of Immigrants in Germany - $\quad 1 / 3 \quad 3 / 00$

Effects of Ethnic Origin and Assimilation. Or:

Who Gains from Income Re-Distribution?

Smoking, Discount Rates, and Returns to

Education

Chain Reaction Approach

Do Unemployment Insurance Recipients Actively

Seek Work? Evidence From Randomized Trials in

Four U.S. States

The Employment, Unemployment and

Unemployment Compensation Benefits of Immigrants

$5 \quad 3 / 00$

3

$3 / 00$

6

$3 / 00$

The Returns to Education in Italy: A New Look at

the Evidence

$1 / 3$

$3 / 00$

Are Immigrants Favorably Self-Selected? An

Economic Analysis
Characteristics of Unemployment Dynamics: The 
Hours and Wages in the Depression: British Engineering, 1926-1938

133 D. N. F. Bell

R. A. Hart

O. Hübler

W. Schwerdt

134 A. D. Kugler

G. Saint-Paul

135 A. Barrett

P. J. O'Connell

136 M. Bräuninger

M. Pannenberg

137 J.-St. Pischke

138 J. Zweimüller

R. Winter-Ebmer

139 R. A. Hart

Y. Ma

140 G. Brunello

S. Comi

141 R. Hujer

M. Wellner

142 J. J. Dolado

F. Felgueroso

J. F. Jimeno

143 P. J. Luke

M. E. Schaffer

144 G. Saint-Paul

145 M.-S. Yun

146 T. K. Bauer

J. P. Haisken-DeNew

147 M. Belot

J. C. van Ours

148 L. Goerke

149 R. Lalive

J. C. van Ours

J. Zweimüller
Paid and Unpaid Overtime Working in Germany and 1 the UK

$3 / 00$

Hiring and Firing Costs, Adverse Selection and

3

$3 / 00$

Long-term Unemployment

Is There a Wage Premium for Returning Irish

1

$3 / 00$

Migrants?

Unemployment and Productivity Growth: An

3

$3 / 00$

Empirical Analysis within the Augmented Solow

Model

Continuous Training in Germany

$3 / 00$

Firm-specific Training: Consequences for Job

$3 / 00$

Mobility

Wages, Hours and Human Capital over the

Life Cycle

Education and Earnings Growth: Evidence from $11 \quad 2 / 5 \quad 4 / 00$

European Countries

The Effects of Public Sector Sponsored Training on

Individual Employment Performance in East

Germany

Explaining Youth Labor Market Problems in Spain: 3

Crowding-Out, Institutions, or Technology Shifts?

$4 / 00$

Wage Determination in Russia: An Econometric 4

Investigation

Flexibility vs. Rigidity: Does Spain have the worst of 1 both Worlds?

Decomposition Analysis for a Binary Choice Model

Employer Learning and the Returns to Schooling

Does the Recent Success of Some OECD

Countries in Lowering their Unemployment Rates

Lie in the Clever Design of their Labour Market

Reforms?

Employment Effects of Labour Taxation in an Efficiency Wage Model with Alternative Budget Constraints and Time Horizons

The Impact of Active Labor Market Programs and Benefit Entitlement Rules on the Duration of Unemployment
7

$4 / 00$

5

$4 / 00$

$4 / 00$

$4 / 00$

$3 \quad 4 / 00$

3

$5 / 00$

$3 / 6 \quad 5 / 00$ 
J.-St Pischke

151 M. Ward

152 J. J. Dolado

F. Felgueroso

J. F. Jimeno

153 A. S. Kalwij

M. Gregory

154 Michael Gerfin Michael Lechner

155

J. Hansen

156

157

158
A. Björklund
T. Eriksson
M. Jäntti
O. Raaum
E. Österbacka

159 P.- J. Jost

M. Kräkel

160

M. Lofstrom
Gender, Salary and Promotion in the Academic 5 Profession

The Role of the Minimum Wage in the Welfare 3 State: An Appraisal

Overtime Hours in Great Britain over the Period 3 1975-1999: A Panel Data Analysis

Microeconometric Evaluation of the Active Labour 6 Market Policy in Switzerland

The Duration of Immigrants' Unemployment Spells: $\quad 1 / 3$ Evidence from Sweden

Language Proficiency and Labour Market Per- 1 formance of Immigrants in the UK

Household Production, Full Consumption and the Costs of Children

Brother Correlations in Earnings in Denmark, 5 Finland, Norway and Sweden Compared to the United States

Preemptive Behavior in Sequential Tournaments

A Comparison of the Human Capital and Signaling 5 $6 / 00$ Models: The Case of the Self-Employed and the Increase in the Schooling Premium in the 1980's 